\title{
Biopolitics and the Infected Community: Foucault, Sartre, Esposito, and Butler
}

\author{
Bradley Kaye
}

When Michel Foucault enumerated the various ways that bio-politics emerges he pinpointed it as an outgrowth of patria potestas or the paternalistic power over life. It was the father in Roman Society who had the ability to "dispose" of the lives of slaves and children. Theorists have reacted to Foucault's insights with the most important extension of this work done by Roberto Esposito and Giorgio Agamben. Agamben locates the origins of biopolitics in Ancient Roman Law, and his thesis is that every life must remain sacred in order to counter-act the degradation of "disposable" life.

Early on in Foucault's career in his "experience book" History of Madness he was writing in direct response to the existentialist politics of Jean-Paul Sartre expressed so eloquently in Being and Nothingness. Foucault's immediate political engagements were in direct response to the notion that agency could only be construed by utilizing a Cartesian conception of the Subject. A critique of Sartre was still very much in his mind later on in his life when he began to unravel bio-politics later on in his work on sexuality. Michel Foucault's praxis is a non-totalizing theory that must be placed in conversation with his entire oeuvre.

If philosophers take biopolitics to its conclusion and "cut off the head of the king" as Foucault said had never been done in political theory, it becomes a powerful rebuttal to the tiresome political theory of the "philosopher kings" who want nothing more than to whisper sweet nothings into the ear of the sovereign. Can political theory be something more than a simplistic love/hate relationship with the state? Can it be something other than the dysfunction of party hacks filling the proletariat with fear of this or that pseudo-controversy; caught between the pettiness of the petit-bourgeoisie, and the boorishness of the proletariat there needs to be a different way to understand political discourse. Can there be a community where its telos is something else besides a fantasy that ends with everyone becoming millionaires at the end. Can there be an understanding that liberalism as it currently stands also messes with the working class; in reading the full quote from Deleuze in Anti-Oedipus; "Why do people fight for their servitude as if it were their salvation, crying more taxes less bread" is not a cry for social-democracy and liberal party politics but full anarcho-communism. There is no "essence" to be revealed beneath the surface level of false consciousness and faulty ideas.

One major concern with this line of thought is that it can be Occidentalist in nature. Did the Aztecs experience sacred life in the same way as the Romans? Does the Japanese Emperor have the same sacred meaning for the Japanese people as the Pope for the followers of the Catholic Church? These are major concerns and to think that all states operate the same way is to have a homogenized view of history.

Can there be a multi-cultural pluralistic method to uncover a universalist ground to ontology? It seems that this is the major impasse of leftist political theory over the last forty to fifty years. Every time a political theorist discovers what amounts to a universal principle of the "being of beings" one is immediately labelled a Eurocentric, or Masculinist, or limiting the question to being merely a homogenous totality. One begins to discern from this impasse that totalities are akin to state power that place limitations on the plurality of differences and thereby territorialize the being of beings. Can theorists think in other terms? We can think of the thing in itself but only as an abstraction because our approach is always muddled. As human beings we have emotions, impulses, and our attention tends to be distracted. Prolonged research over lengthy periods of time is a luxury of a few scholars and 
yet, we turn to these scholars who have devoted their lives to these questions to better understand the long view of history. There are some aspects of biopolitics that are new to contemporary capitalism but there are latent kernels sprinkled throughout Western History that have become manifest as time passes and tropes solidify into the metanarrative mythos of what passes as Universal History.

In understanding the primacy of state power over life, Foucault traces this back to the Roman family structure which became the Western template for governmentality. In this family structure Father had the right to kill any wives, children, or slaves and the sovereign when posed with direct danger could have the right to kill his subjects. Therefore, these sub-human lives were considered disposable (a point that Giorgio Agamben has brilliantly exposed in his analysis of "bare life" as disposable life in most of his works).

However, Foucault claims that this direct power to take lives has been sublimated and redirected externally elsewhere. Now, when the sovereign has an attack on power, where the sovereign's life is in danger, it is within the state's power to kill the subjects by redirecting their energy into war. It is not direct killing of the subjects by the sovereign, but a redirecting of libidinal energies into the fascism of total war.

It was no longer considered that this power of the sovereign over his subjects could be exercised in an absolute and unconditional way, but only in cases where the sovereign's very existence was in jeopardy: a sort of right of rejoinder. If he were threatened by external enemies who sought to overthrow him or contest his rights, he could then legitimately wage war, and require his subjects to take part in the defense of the state; without directly proposing their death, he was empowered to expose their life: in this sense, he wielded an indirect power over them of life and death. (Foucault, 1978, 135)

The state is analogous to the paternalistic family structure, the Roman "Father" looking after its subjects for their own good, disposing of life at any time. There are also ways that the creeping state presence in a bureaucratic Western society creates repressive social modalities that eventually bring every aspect of society under its regulating gaze via the normative aspects of legal state apparatuses. The father's no has become the yes of consumerism. I will try to construct a viable set of ideological alternatives by juxtaposing the differences between Michel Foucault and Jean-Paul Sartre.

In bio-politics risk is spread out over the entire population as:

Wars are no longer waged in the name of a sovereign who must be defended; they are waged on behalf of the existence of everyone; entire populations are mobilized for the purpose of wholesale slaughter in the name of life necessity: massacres have become vital. It is as managers of life and survival, of bodies and the race, that so many regimes have been able to wage so many wars, causing so many men to be killed. (Foucault, 1978, 137)

As life is exposed it becomes "bare life" increasingly informed by the naked question of survival. In the seventies there was a push towards nuclear disarmament a major question that still lingers, and Foucault presses the issue by saying: "The atomic situation is now at the end point of this process: the power to expose a whole population to death is the underside of the power to guarantee an individual's continued existence." (ibid.) Now that his lectures have been published we can see in Society Must be Defended; Security, Territory, Population; The Birth of Biopolitics; and elsewhere how his research on this issue was shaped by textual references within the canonical traditions of philosophy, in particular by many of the Enlightenment Period political philosophers such as Hobbes and Bentham. His work also stems up to the Nazi thinkers and the American neo-liberal capitalist reactions to the rise of Fascism bred by a total and complete paranoia of any state intervention into daily life. All of that has been in the name of biopolitics.

Is there an anti-essentialist dimension to even biopolitics? It is hard to pigeon hole Foucault as a philosopher of the institutional aspects of power when he says point blank: "One needs to be nominalistic, no doubt: power is not an institution, and not a structure; neither is it a certain strength we are endowed with; it is the name that one attributes to a complex strategical situation in a particular society" (Foucault, History of Sexuality Volume 1, pg. 93). When I talk with even learned scholars about Foucault there is still a weird idea that he only talks of institutional aspects of power.

Discipline and Punish was a political intervention at a particular moment in the early seventies when the prison population was spiraling out of control and my hypothesis is the state was criminalizing minor drug offenses and locking people away as a tactical maneuver to suppress the resistance that had gained popularity in the sixties and seventies which was when the Rockefeller Drug Laws began to take effect; this is also when the problem of prison overcrowding became a major problem which required a move towards prison abolition. History of Madness was written in the early sixties at the beginning of psychoanalysis as a serious medical discourse and psychiatry with talk therapy was starting to gain traction as a widely accepted social phenomenon. As Foucault points out though, these 
were all methods of creating spaces of incarceration and modes of surveillance on the criminal and mad populations that were deemed to be political threats to the state due to living by non-normative behaviors. The criminalization of madness was also a major tactic of repressive political discourses at that time, which still exist as tropes to this day. As a result of these social institutions the mental hospital and the prison gaining ascendancy as repressive apparatuses that incarcerate and create surveillance the result was a mass homogenization of experience and a total fear that lead to the post-modern surface level "fluffy" simulacrum life experience where every social interaction was an interaction at the level of superficiality.

Digging into the depths of the psyche to do the hard inner work of self-transformation would lead to unleashing the negativity that pent up as a result of being harassed by these repressive political institutions. The age-regressions that occur when someone is made slightly uncomfortable when in the seventies capitalism was moving more towards a service economy, retail, office jobs, therapy, health fields, and this leads to the stroking of the bourgeois and petit bourgeois ego from all sides by capitalist consumerism that serves everyone and says "Yes" to any desire. Lower classes are being incarcerated in massive proportions especially racial minorities in the United States. But, in the midst of this, impatience with any subtlety has grown prevalent and the big issue now is that capitalism always says yes, even to the most perverse desires and horrific violent transgressions. Experiences can be bought at least as simulacrums in virtual or tele-visual forms. Acting out in a repressive society has taken the form of simulated acting out, actors acting out parts on television and in movies, but in reality workers (and especially women) are more repressed now than ever before. Now truth has become nothing more than accrued habits and whatever helps everyone feel comfortable and satisfied.

For some reason the discourse of bio-politics is extremely seductive in garnering support for American imperialistic endeavors abroad, the subjects seem to turn a blind eye to the violence inflicted by the US Military when it is conducted as a humanitarian "peace-keeping" mission. Or, as Roberto Esposito points out the way of garnering the alleged consent of the masses for a war effort is by positing the necessity to take life in order to preserve life. Often in Bosnia, Iraq, Afghanistan and Libya, the US Government bombed the so-called enemies while they also air dropped medical supplies. The taking of life is problematically coupled with the desire for immunization, to create death and destruction while also trying to sanitize, clean up, and "fix" the broken situation.

The Affordable Care Act is no such exception to the rule. It tries to offer healthcare to workers who will remain productive in an effort to maintain the working class as healthy subjects, but it is a prescriptive measure designed to put a band-aid on the problems of health that arise when the workers are worn down due to frenetic bodily activities of manual labor, and the stasis of intellectual immaterial office work which contributes to certain health risks such as obesity. It is the bio-political ethos in praxis, because the predominant political discourse surrounding the pro and con positions regarding the reforms was almost always economic in nature. Does the policy save consumers money? Does it save the government money? Nowhere in the discussion was there any analysis that perhaps capitalism contributes to these health related issues that need preventative care, or in the pseudo-debates about veterans' health care that their health problems are a direct result of bio-political discourses that provoked wars over the last ten to twenty years. There is a certain matrix by which the bio-political conversation has continued unabated.

I would like to add two supplemental charts which may outline a very important point. The illusion of choice. This chart shows the mass consolidation of ownership of what Gramsci called the 'dominant discourses' to win the consent of the masses. What Althusser called the "Ideological State Apparatuses" the institutions that create sympathy for hegemonic ideologies.

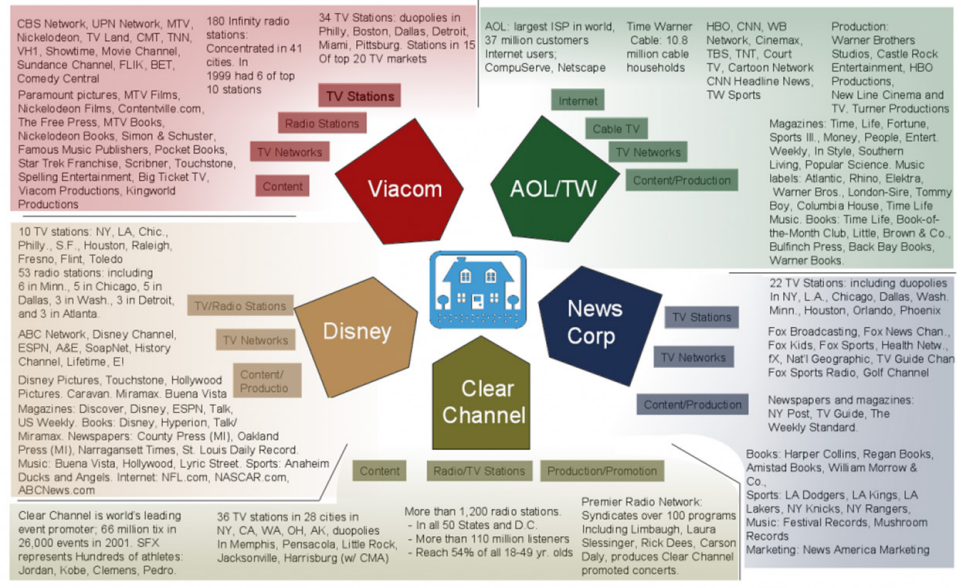


I could not find the original source for this chart, but it was widely shared on Reddit.com and shows the mass consolidation of power in the modes of food production.

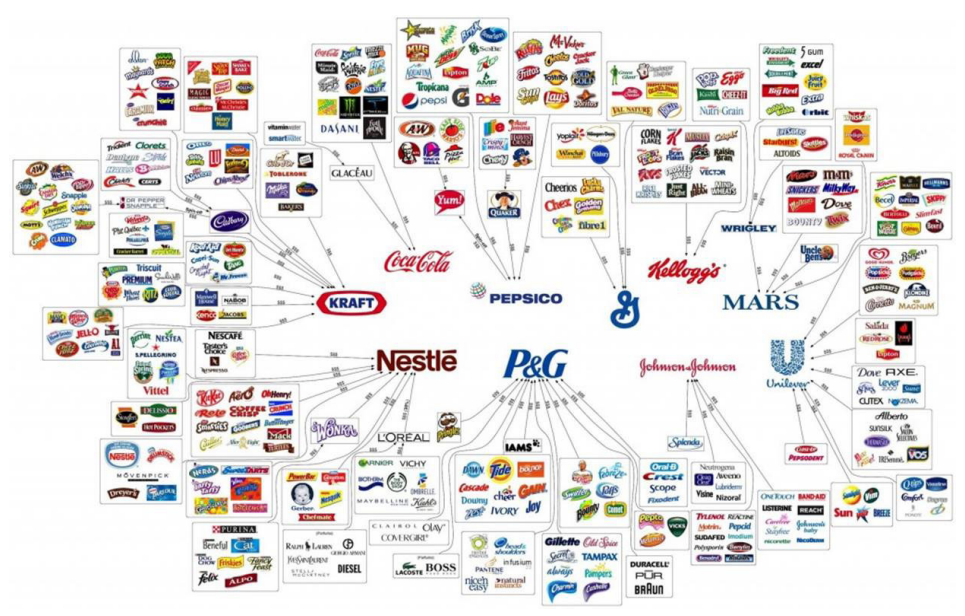

Thomas Pynchon is brilliant at 'fictionalizing' a sort of conspiratorial causality where the government works to cause problems while selling the public the immunizations that may save us. I find it interesting that at the same time when Barack Obama was attempting to pass his Affordable Care Act, the signature accomplishment of his terms as President, shortly thereafter on March 26, 2013 after much protest and without much attention from the press gave special accommodations to the largest genetic engineering corporation in the world in the form of H.R. 933, the Monsanto Protection Act. Anyone who follows health and wellness knows that Monsanto is the corporation responsible for most of the genetic alterations in our foods which has most likely caused many of the gluten and peanut allergies, caused type 2 diabetes in children by adding sick amounts of sugar to our dairy supply.[1]

Will there be any freedom at all in the next century? In the midst of these conversations there is a nefarious granularity or specificity that clouds the problematic metaphysics of the ongoing discussions. As Althusser was right to point out, capitalism has interpolating processes that call the subjugated subjects as individuals. This granularity of individual conscience can impede the forward thrust of history, and this how I view the impasse in thinking between Jean-Paul Sartre and Michel Foucault. Jean-Paul Sartre hated the granularity of bourgeois idle chatter in his famous line, "Hell is other people" which expresses a strong sense of anxiety over simple-minded self-indulgent small talk and gossip that impedes the power of praxis in the conversations that go on in the environment of the salon.

In the introduction to Being and Nothingness, the entire first section of the book is about ridding the subject of an "interior" that makes the dualism of "being and appearance" completely absurd. The "Pre-Reflective Cogito" there is a core to the subject that can be traced to its external negation which can be unwound via the overturning of "bad faith" in the subject that carries negative, cynical, attitudes about him/herself. The subject that is anything but a "Not;" Sartre is all to skeptical that most people will never overcome their position as a "not." As he says, "There are even men (e.g. caretakers, overseers, gaolers) whose social reality is uniquely that of the Not, who will live and die, having forever been only a Not upon the earth" (Sartre, Being and Nothingness, pg. 47). In bringing this act of negation into conversation with biopolitics, Nikolas Luhmann is a thinker whose work arrived at the radical consequences of "immunization" in saying that: "the system does not immunize itself against the no but with the help of the no" or, "to put this in terms of an older distinction, it protects through negation against annihilation" (qtd in Esposito, Bios, pg.49). The thesis being that biopolitical systems function not by rejecting conflicts and contradictions, but by placing them in the body as necessary antigens that reactivate natural anti-bodies. To put madness in the context of this therapeutic framework, as R.D. Laing one said, madness is not all break-down, it is sometimes also a breakthrough.

It is the commonality of experience tied together through that artificial individuation constituted properly by the sovereign dispositif, and as Esposito claims, there is an external negation to bio-politics: "Sovereignty is the not being (il non essere) in common of individuals, the political form of their desocialization" (Esposito, Bios, pg. 61). There is negativity to immunization, a push-back on behalf of the population that is being inoculated, a stubborn deathdrive; particularly in mad-subjects in my field work there is a desire to cling to the disease, the damage, the broken 
frailty, the imperfect eccentric identity that meshes with the diagnostic labels that have been externally imposed upon the subjects.

Bad faith is a self-negation that doubts, questions, second guesses the self-inflicted inwardness absorbed through cultural cynicism normalized as if it were human nature. In this sense, Sartrean liberation is conducted as the process of moving from self-negation to a the almost reflexive, outward agency of positivity ala "good faith" reminiscent of Max Stirner's ego of agency. Jean-Paul Sartre is still operating within the nexus of the "repressive hypothesis;" liberation as negating the myth of the repression carried over from previous historical episteme by turning the No into a Yes. The modernist Joycean liberation as "saying Yes, to his Yes," and getting everyone to the big O, but as Slavoj Zizek points out, this is exactly what feeds into the power matrices of post-modern open ended oppression. Even in the indecision between Yes and No we always claim to reduce indecision through the rules of Logic to a unitary One.

Why is there this injunction to enjoy? Does it not merely reproduce and codify new forms of control and normative disciplinary structures as the bio-politics that creates "life" via the open expression of its creative vitalism without truly negating the underlying, material prison like structures that remain in place in contemporary capitalism? You can engage in whatever sexual lifestyle you want as long as you report to work at a corporation and obey the state, subject yourself to its constant NSA surveillance, and as long as the basic discourses that support the violence of bio-politics remain in-tact, everything else is fair game. It is more cogent to frame oppression in the context of immunization and biopolitics, the politics of life, rather than the politics of enjoyment and expression.

Gilles Deleuze was correct in asserting that there are individual forms of repression, but in societies of control, one must also be concerned with "dividual" oppression. Dividual oppression is the existence of the subject within the digital relations, the credit report, the use of a social security card, bank accounts, the personal identity that is handed over to corporations and the state in the computer era is so much more oppressive because all of the damage and surveillance that is done to the subject is concealed from sight. Unbeknownst to the individual, the virtual space of the "dividual" identity can be totally destroyed, and ultimately lead to the oppression and downfall of the individual in its actual, material, lived experience in reality. One can be denied housing, or an automobile, or health insurance, or a bank account, or be wrongfully incarcerated and denied any other basic necessities that one needs in modern capitalist society to survive and maintain a productive life.

This is where Jean-Paul Sartre did not go far enough, and where Michel Foucault is far more radical, and ultimately correct in his assertions. The distinguishing feature between Sartre and Foucault is Sartre's belief in consciousness. Since Foucault openly criticized the position of intellectuals within the university's "power/knowledge" apparatuses, the question of his work being a systematic unraveling of a position given from a place of authority is problematic. Foucault favored praxis as a non-totalizing theory and he says this: "In this sense, theory does not express, translate, or serve to apply to practice; it is practice. But it is local and regional, as (Deleuze) said, and not totalizing" (Foucault, Language, Counter-Memory, Practice, pg. 208). The praxis of a theory that moves through the circuitry, relays, networks, and channels of power in the creation of a subterranean anti-hegemonic bloc, rather than the Stirnerian "ego of agency" where consciousness is raised and the knowing powerful subject goes out and changes the world. It was Deleuze who best understood Foucault's position on power:

As the postulate of property, power would be the 'property' won by a class. Foucault shows that power does not come about in this way: it is less property than a strategy, and its effects cannot be attributed to an appropriation 'but to dispositions, maneuvers, tactics, techniques, functionings'; it is exercised rather than possessed, it is not the privilege acquired or preserved, of the dominant class, but the overall effect of its strategic positions. (Deleuze, Foucault, pg. 25)

There are innumerable points of conflict and places of instability that open up in this way of understanding power. It unravels via the confrontation with the micro-politics of everyday fascism, millions of little revolutions spread out over an entire social field, rather than the storming of the state, smashing it, redistributing wealth, and then recreating masters and slaves all over again. This is a much more gradual almost glacial pace by which the stubborn dimension of creating a subterranean anti-hegemonic bloc contrary to the discourses of "intelligence" in the power/knowledge matrices.

All too often the media posits itself as a meta-salon. It is important for a truth discourse to break through the white noise of the media-salon to liberate discourse from the labyrinth of competing and overlapping interests that become inscribed upon consumers of the ideological state apparatuses. Interpellation and aestheticizing en masse via the personal sensitive touch of the cold heartless head of state can be a powerful impediment to this kind of critique. The humanization of the brutal sovereign - the bêtise - the stupidity of the monster, the sovereignty of 
the animal, as Deleuze called it in Difference and Repetition, who eventually inspired Derrida to focus on this issue at length as well.

In Foucault, there is a movement towards an "ec-centric" or "ex-orbitant" subject that Western humanist discourses have sought to discipline and reform via assimilation into its symbolic order. The mad-center-elsewhere, or the madness that is perpetually subjected to disciplinary measures of diagnostic, taxonomical classifications, with medicine being more akin to a "teratology" (a study on the classification of monsters) - and the telos of striving to tame these monsters, with the underlying presupposition always being that the 'monster' is in need of morals, or that the violence conducted upon the mad is necessary as a preventative security measure to protect the masses "for their own good;" because as Foucault was right to point out in Society Must be Defended, the state always tries to express political discourse as war by other means. Political discourse has become hegemonic blocs with overlapping competing interests in trench warfare against one another stuck in their foxhole. Or that the violence inflicted upon the mad via the repression of analysis reproduces the violence that occurs in the mad subject.

The monster is the body of possibility, of a being that could be completely external to the normative biases that cloud the predominant political truth regimes. The gatekeepers and deputies of the dominant discourses are afraid of madness and this fear continues through to the petrified ambassadors of civility and civilization who try everything in their power to discipline and make the mad normal. In the History of Madness I do not see a lot of discourses, but I do see communities opening up to the mad, and then the mad pose a threat to the immunity of the community. They are codified as diseased via their original relation in medical discourse to the leper (leper colonies were transformed into psychiatric hospitals in France after the Black Plague). There is a conflict between Christian Charity and Pity towards the mad.

Does the community welcome the mad who will then "infect" the sanctity of the allegedly pristine collective bringing sin into the City of God, thereby bringing God's wrath upon the people? Or do they drive out the mad who are then ostracized? This conundrum usually ends with the process of self-enrichment placed upon the allegedly broken mad-subject who are then "educated," "liberated," and "domesticated" by being taught to unlearn their bad habits so as to fit in with the prevailing Christian sanctimonious ethos of clean, happy, docile, useful, subjects. Normative cultures of all epochs and epistemes usher in "new" methods by which the mad are handled in exactly the same way. The raw material of insanity is worked over to become a "finished good:" morally, economically, politically, and even aesthetically. This is all a way of eliminating the eccentricity of limit-experiences and the madness of "losing one's face" ripping oneself apart via experience books to become a totally new person. If man is a "rational animal" as Aristotle wrote, then animals heavily figure in the symbolic representations of madness that have arisen in Western culture. Animals are stand-ins, body-doubles for the mad. Madness is the denaturalized violence of animals in nature, and if the mad are "irrational" then the mad are nothing more than sub-human species in this Aristotelian understanding of human nature. Jean-Paul Sartre is still attempting to interpellate "rational animals" in his attachment to the Cartesian Cogito. Sartre uses the aesthetics of language to create poems and beautifully worded philosophical positions akin to Buddhist Koans in knowing that logic does not adequately function as a necessary means to understanding reality and metaphysics. Sartre still posits the Subject as a rational, sane actor. Sartre is still trying to build the City of God as constructed by an Atheist socialist with a nihilistic face.

In the Heideggerian vicissitudes that creep into Foucault's work, the act of interpreting "the mad" is not intended to break through false consciousness, or false representations to an ontological essence of Truth, or to bring pure Being into immediate view in the sense of closing off distance between the perceiving subject and the being it would re-present. Madness is the absent Real that is always already a historically specific inscription within history's disciplinary structures that are implicated in the violence against/committed by the mad. The suppression of madness and its liberation as an epistemological object is merely the transposition of one normative disciplinary structure for another normative disciplinary structure. These are tactics employed to ensnare madness in a normalizing regulatory gaze that codifies it as dysfunctional, broken, abnormal, deviant, criminal, and a monstrous-Other to be tamed. As Foucault claims in Discipline and Punish: "Visilibility is a trap" (Foucault, Discipline and Punish, pg. 200) and again:

Thanks to the mechanisms of observation, it gains efficiency and in the ability to penetrate into men's behavior; knowledge follows the advances of power, discovering new objects of knowledge over all the surfaces on which power is exercised. (Foucault, Discipline and Punish, pg. 204)

How much more critical of Hegel's Master-Slave Dialectic can you get here? Foucault is obliterating the ethos posited by Hegel that power is about recognition. In the master-slave dialectic the master controls the slave by somehow getting the slave to passionately care about recognition in the eyes of the master, making honor and praise 
visible, transferring and transcribing virtue onto the body of the slave, is a timeless way to warp everyone into actually believing they are not slaves. This is how the entire monetary system functions in the psyche of those who are buy into commodity fetishism hook line and sinker; through libidinal investments in the decorum of "recognition" - a wage is the slaves recognition for a job well done in the service of capitalism. Either you become instrumental cogs in this fascist machine or you are cast aside as mere human debris. Simple as that there are no other choices in real subsumption, because all aspects of life are products of the market; even the aspiring entrepreneur who blazes a new frontier has to produce something in response to a market need in order to create wealth, there has to be a need to transfer money into the hands of that business. There are no solipsisitic billionaries, but there are narcissistic ones, that is a subtle difference, you can argue that all that is solid melts into air and that the foundational grounds of morality are ethereal in capitalism, but to actually posit the non-existence of material realm is to be mad.

If madess is construed as criminal it is also subject to the Panoptic Gaze as well as the Medical Gaze that regulates all aspects of life through constant surveillance in the biopolitical realm that constitutes the impasse of the current conjuncture in late capitalism. In describing the Panopticon, there is a sense that life is at stake in that it immunizes and corrects the behavior of the deviant criminal in that it assures its disciplinary efficacy by its "preventative character, its continuous functioning, and its automatic mechanisms" (Foucault, Discipline and Punish, pg. 206). The process of instilling morals becomes the second nature of the imprisoned/incarcerated individual in the austere institutions that are all around the subject in modern life; the barracks, the family at home, the school, the prison, the corporation, and the hospital all become loci and biopolitical battlefields connected in a network of relations pinned together by the Panopticon, which as Foucault posits: "Is a marvelous machine which, whatever use one may wish to put it to, produces homogeneous effects of power" (Foucault, Discipline and Punish, pg. 202).

One must look at the Foucauldean inversion of the Platonic Soul in the Phaedo where the body is the prison of the soul. In disciplinary power the soul is the prison of the body. Normative aspects of morality become second nature and appear as the inner dialogue of the conscience of the moral person. However, there is another thread in Foucault that is an homage to Georges Bataille and Friedrich Nietzsche. Consisting of breaking with the habitual behaviors of banal bourgeois life by escalating consciousness into the "white heat" of libidinal passion to borrow from Bataille; or the Dionysian Spirit to borrow from Nietzsche. Limit experiences at the threshold of consciousness where freedom is experienced as the meltdown of all rationality.

The meta-discourses of bio-politics keep the conversation clean for political reasons and the sanitized (or rather, sane-itized) structures of these discourses try to maintain hegemony via: "a faceless gaze that transformed the whole social body into a field of perception: thousands of eyes posted everywhere, mobile attentions ever on the alert, a long, hierarchized network..." (Foucault, ibid, pg. 214).

Through the meta-discipline of this homogeneous panoptic discourse, the sovereign accustoms the people to order and obedience, as if the people had a voice, as if there is a state that listens, cares, and pays attention to the problems of the people. Disciplinary power creates constituent power in the form of technologies of the self that produce docile, useful, malleable, and easily exploitable labor-power that can continue into the "fields:" the factories, the universities, and now the corporations. It is rather interesting to me that the writers Foucault claims were his biggest influences were always referred to by him as being external to the dominant academic debates at the time. Names like Nietzsche, Bataille, and Blanchot form the nexus by which he rallied against the suffocating groupthink mentality of the communist parties in France in the 1950's; he was also trying to put forth a different approach to radical politics beyond the realm of the Marx-Freud fusions of the Frankfurt School.

He writes, putting forth a totally different approach to power, that goes against the common understanding that he was only interested in the topic of "institutional power:"

Discipline may be identified neither with an institution nor with an apparatus; it is a type of power, a modality for its exercise, comprising a whole set of instruments, techniques, procedures, levels of application, targets; it is a 'physics' or an 'anatomy' of power, a technology. (Foucault, Discipline and Punish, pg. 215)

If institutional power is important it is as a method of providing decorum and the discursive dispersal of signifiers that Power produces.

There is no question that the appearance in nineteenth-century psychiatry, jurisprudence, and literature of a whole series of discourses on the species and subspecies of homosexuality, inversion, pederasty, and psychic hermaphrodism made possible a strong advance of social controls into this area of "perversith;" but it also made possible the formation of a "reverse" discourse: homosexuality began to speak in its own behalf, to demand that its legitimacy or "naturality" be acknowledged, 
often in the same vocabulary, using the same categories by which it was medically disqualified. There is not, on the one side, a discourse of power, and opposite it, another discourse that runs counter to it. Discourses are tactical elements or blocks operating in the field of force relations. (Foucault, History of Sexuality Volume 1, pg. 101-2)

And much more concrete to the point: "Power is everywhere, not because it embraces everything, but because it comes from everywhere. And 'Power,' insofar as it is permanent, repetitious, inert, and self-reproducing, is simply the over-all effect that emerges from all these mobilities, the concatenation that rests on each of them and seeks in turn to arrest their movement" (ibid. pg. 93). The entire chapter entitled "Method" in the first volume of the History of Sexuality puts a fine point on Foucault's entire oeuvre.

It is clear that in these passages there are some aporias to be unpacked. How can power be everywhere as an implacable set of flows in the sense of a physics of power? It sounds appropriated from Nietzsche's active and passive power with the added dimension of discursivity that perpetually bifurcates power into resistance against itself, which transforms its base. And then, he has quasi-essentialist tendencies, but he has to add the cautious "Power," insofar as it is permanent; the key here is "insofar" which leads me to believe that he is skeptical about the permanence of any structures of power; be they institutional or discursive. Especially when he follows up with the conclusion that the alleged permanent aspects of power are a result of "all these mobilities;" it is unclear what he means by "mobilities?" I would presume, and I could be wrong, but my hypothesis is that it is another mode of circulation as a political-libidinal-economics. Mobility of labor; but sexual labor; the movement of bodies that transgress the immobilizing territorializing aspects of the repression of the Law. He is very clear at the beginning of the Method chapter that he is putting forth an analysis of sexuality that is done, "not in terms of repression or law, but in terms of power" (ibid. 92). Power and power as akin to Being and beings; there are meta and micro levels of power which interact often pushing against one another which causes friction and much like electricity; this friction also releases power, which is empowering and oppressive simultaneously, it is not either or in a binary distinction where these two concepts are separate; power enmeshes everything, even that which resists. One professor of mine in graduate school once said that there were no Althusserians but to me, this is the most Althusserian move that Foucault ever makes. He is showing how Power reproduces itself through the epigones it creates that then echo back to itself the desire to make chains an essential complement to its liberation. These bifurcations of Power/power are bound together through a traumatic wound that eventually scars and never goes away, repeated/resurrected through painful tropes of Historical consciousness. Quite possibly all we have are specters and ghosts to illuminate the present and indicate our transformations into the future. Through the sheer inertia of History, Power replicates itself as it sends off sparks that ignite new passions and new fires through the friction of mobility. In this sense, even in Foucault we are immanent in the realm of the Nomadology.

It is bizarre how on the one hand American capitalism tries to open up borders for trade and make the economy more mobile for itself through free trade agreements like NAFTA. While simultaneously stirring up xenophobic hatred towards the disenfranchised laborers who try to traverse these borders into the United States; often in pursuit of something simple like a minimum wage. It is much more complex issue than simply rabble rousing about building walls to keep immigrants out while accelerating the accumulation of capital by allowing trans-national corporations to freely traverse these borders. Borders are there for the lower classes; much like how Nietzsche discovered that morality is for the slave-classes. Unfortunately, the economic despair produced by these free trade agreements increases pressure and pushes potential energy into kinetic energy as it is released when immigrant populations are perpetually circulating across the borders. The hard truth is that these borders are juridical constructions that perpetuate racial hatred between the "beings" to divert attention from Beings.

Again with the term "Method" he is thinking of an epistemology of Power/knowledge. To know how power inscribes itself down to the capillaries of the subject is to turn existentialism in on itself. Sartre seems like a naive schoolboy to think that anyone is ever an autonomous free individual. The problem is the repetition of historical tropes in the psyche of the subject (the torrid history of racism for example that beckons so many adults who have never learned otherwise). Absolute freedom seems totally undesirable though; and total decoding of all libidinal flows into anti-repression can have the horrifying consequences of degrading beings into primal violence. The missed opportunity there is that Wilhelm Reich did not meet Michel Foucault.

Foucault is clearly distancing his interpretation of power from that of Thomas Hobbes' Leviathan; the head of a monolithic state as the ravaging ruthless animal who will stop at nothing to maintain a position of sovereignty, ruling through the totalitarianism of total fear, and instilling power through the threat of death.

Biopolitics has turned the corner where it now uses the discourse of immunity. Killing so as to clean up the mess 
made by other allegedly sub-human irrational-animals external to the state that are allegedly "mad" enemy-Others who pose security threats to the life of the citizens that the sovereign has sworn to look after and take care of in a fundamentally paternalistic sense of governmentality. The freedom in neo-liberalism is not real freedom it is nothing more than the ignorance of these regulating, normalizing, and determining market factors spearheaded by the state and capital working in collusion with one another holding a duopoly on power. Trading one regime of power for another without changing the prevailing discourses of biopolitics that underpin these structures of violence will do nothing to eventually eradicate the stranglehold that these institutions have upon contemporary society, which give off the impression that the demos is actually free. The biopolitical repression is freedom through non-freedom, peace through war, violence as a helping hand, killing to save lives, health to maintain the exploitation of productive labor, security and surveillance as an ongoing Kafkaesque process of interrogation without a reason that continues "for our own good;" and not true liberation.

Neo-liberal capitalism and the state that does its bidding has been seeping through the United States like a homogenizing-glacier over the last few decades. Gradually subsuming all aspects of life. Freedom is ignorance of the forces that determine our choices. Some Marxists have even termed the current capitalist phase in America, not as a class system, but as a caste system, so with this in mind, what can these theorists tell us about tactical pathways out of the current conjuncture. Now, the privatization of health care and the prison system seems to be the final maneuver to keep this resistance down as there is a profit motive to keeping people sick and on pills, and to keeping people locked up in jail. The repression becomes absolute unless there is a novel becoming that transforms our daily existence where the working class is surrounded by repressive apparatuses at all sides, and the bourgeoisie thumbs their nose at them as if their caste position were a matter of virtue ethics, personal choice, and a lack of moral character. Class is not a moral category it is an economic category due to market driven forces that are outside of the control of the individual

The question becomes: Is it possible to think about life outside of a political context? At the current moment the distinctions between public and private, state and society, local and global divisions are collapsing sources of political legitimacy are also becoming more and more vacuous, and yet, as this seems to bring a new kind of liberation the opposite is happening; as Roberto Esposito says: "life becomes encamped in the center of every political procedure. No other politics is conceivable other than a politics of life, in the objective and subjective sense of the term" (Esposito, Bios, pg. 15).

If the body-politics is conceptualized as a mind-body connection in capitalism with the bourgeoisie being the brain and the proletariat being the body, biopolitics construed this way tends to view dissent as a disease infecting the body as germs which feed off of its vital substance, "degenerating" the body. Immunization being the violent "cure" enacted by state-doctors who clean up the "dirt" and the filth, via the eugenic racial politics of deciding which lives are fit to remain alive. A utopian fantasy that life will triumph and all diseases will be ameliorated, death overcome, is somewhat of a hangover from modern political theory. It has been assumed that Hobbes "not only places the problem of the conservation vitae at the center of his own thought, but conditions it to the subordination of a constitutive power that is external to it, namely, to sovereign power, the immunitary principle has virtually been founded" (Esposito, Bios, pg.46).

Life is expanded via the acceleration of death among remote dissident populations that are beyond the view of the fit, healthy, so-called racially superior classes. In capitalism the appropriation of profits is a zero sum game and it subordinates life to the same exploitative matrices, but then appear as if this is a scientific, and evolutionary fact of nature, rather than a discursive bio-political construction that grafts the body and brain onto politics. All of power/knowledge's dispositifs play the role of protective containment in the face of a vital power (potenza) that is led to expand without limits, via the will to power in the sense described by Nietzsche. This is stifled by the repressive apparatuses of the state (potestas) which attempt, but usually fail, to immobilize the conatus of the oppressed classes who strive towards the power to be, the power to exist, and live within the paradoxical situation of becoming what is (amor fati); rather than what the state says ought to be (utopian socialism).

Literally meaning that the tangible molecular make-up of these organs correspond to an actual structure in the state-apparatuses, with the "germs" and "diseases" being codified as the racially impure populations that were sectioned off from the rest of society in various taxonomical classifications through phrenology and other such exclusionary pseudo-sciences like psychiatry. This type of bio-political fascism has not gone away, it is still going strong, because it posits itself as the natural, scientific and empirically factual truth about human nature and its political manifestations. By studying the effects of bio-power as inscribed upon the bodies of the dissidents, the criminals, the deviants, the lepers that transcribed into the mad, sickness became one of the vehicles of agency in 
Foucault's work. The germs within the body politic causing disruptions, and privileging the corporeal as resistance to framing his work as a consciousness-raising intellectual who places the seat of power in the intelligence of the brain.

It is only from the position of the absolute symptom that one can posit a true understanding of the suffering of the oppressed, and rather than simply inoculate the symptom, one must take a Marxist approach and put forth a radical meta-critique of all aspects of the social-political environment, the base and the superstructure, and then work to radically alter that dysfunctional, alienating set of social relations within that community, and the economic, political structures that condition those relations. While there is an ethical responsibility to maintain the health and vitality of the community, in Western cultures there is a precarious revulsion towards sickness, death, and the eventual breakdown and decrepitude of the body which trickles into the biologically driven representations of the fascist bio-political discourses. This is no way intended to glamorize or sensationalize disease, madness, sickness, and death, but the strange alienation from these facts of life in fascist discourse, the desire to clean up the dirty populations, cure every disease through eugenics, actually creates more sickness, more death, and more destruction. That part of the human experience that the fascists were alienated from, actually becomes exacerbated, multiplied, through its serious repression, there was more death and destruction as a result of the attempts to inoculate the community of its alleged "flaws" and eccentricities.

\section{| Judith Butler's Psychic Life of Power as Panacea to Biopolitic}

Judith Butler does a few things in the Psychic Life of Power that that are groundbreaking. First, she explores the ways in which power forms subjectivity from within the subject. She examines power as inscription from within the subject, at the level of deepest, hidden desires that may be held in secret even to ourselves. Yet she shows that these hidden desires still pull the subject in directions we may be unable to fully cope with. Appropriating power and making it our own does not effectively distinguish the self from the power that relates to it from within.

Conclusively, the appropriative dimension of power insinuates that a subject simply puts its own verbiage onto the power that grafts itself upon the subject's psyche. The fact that we can articulate our own ideological position within capitalism, via the illusion of free will, does not mean that we are somehow liberated from the apparatuses of capitalism. It is precisely Judith Butler's point that the immanence of power that constitutes the domain wherein power forms a subjugated subject par excellence.

The subject's way of thinking and being in the world is possible in the context of power that allows a subject to appropriate a subjugated position within the symbolic order. We are free insofar as we select the modus operandi of a subjection that is own-most. The irony is that we, as subjects, are stubbornly attached to the instruments of our subordination, and yet expropriate all that we work to create. Subjection happens even at the level of the intimate modes of poiesis that produce our conception of "selfhood." It happens by giving the product of our labor to a "Lord/Bourgeoisie" class only interested in "Our/the Bondsman's" labor if it creates a product to be sold. Inexplicably, the Lord, who then sells tangible-material and/or ontological properties, as if it were not the Bondsman's, takes that which is produced away. Thus appropriating a product at the level of producing a self or an identity that is alien to the subject. In the sense of a Derridean specter haunting the Bondsman's being (s)he becomes possessed by the Lord. Selfhood is constructed out of nothing, a nothing that is actually something menacing and anxiety inducing, but that must be given away. My reading of Butler in this chapter deals with how this problematic power-dynamic can be construed immanently as going on within the subject's psyche. My intention is similar to Butler's stated purpose in The Psychic Life of Power insofar as this is an attempt to draw awareness to a particular discursive process producing subjection. This attempt to make sense of subjection will in itself raise awareness and hopefully lead to liberation once the awareness occurs.

Judith Butler's points in The Psychic Life of Power are quite complex, and deeply profound. My first impression was that she leaves little room to escape from the intricate, immanent, and intimate workings of power. It seems that for Butler, as with Foucault, there is virtually no space for alterity beyond the realm of discursivity. Yet, ironically the grounding of resistance emerges out of the excess of power arising from within a particularly abusive sociopolitical system. Judith Butler challenges her audience to deal with the possibility that power relates to a subject via immanence instead of via transcendence. The terrain in this text occurs primarily in the realm of immanence, albeit by evoking problematic ways power takes hold of a subject from "within."

For Butler, power is enacted at the psychical level, an observation that is not necessarily new because critical 
theorists from the early Frankfurt School were saying this in their attempts to fuse Marx and Freud in the 1940-70's. Yet, her basic presupposition challenges her audience to think through the possibility that power is not "out there," in the sense that a subject is not detached from that which it attempts to resist. While the basic problem of Western Marxism has been - "Why is there yet to be a communist revolution in the West?" Butler turns the Master/Slave dialectic into an analogy for any number of resistances that bear an affinity to the communist cause, but also work to liberate subjects at the level of bodily, corporeal, even psychical forms of oppression. To me the importance of The Psychic Life of Power cannot be discounted.

In another text written a few years earlier by Judith Butler, Bodies That Matter, she claims that the "materiality" of the body, within the domain of science, calls to be explained, described, diagnosed, altered and within the cultural fabric of lived experience. Her thesis at that time was that a body is fed, exercised, mobilized, put to sleep, and constitutes a site of enactments and passions of various kinds. Yet she notes that without the body there would be no site upon which the psyche could be enacted. She describes the relation between the body and the psyche by arguing that this relation is: "Not the blank slate or passive medium upon which the psyche acts, but, rather, the constitutive demand that mobilizes psychic action from the start, that is that very mobilization, and in its transmuted and projected bodily form, remains (linked to) that psyche.[2]"

This is an important point to make because the dynamic between the body and the psyche forms the supple ground upon which the immanence of power produces the formation of the subject. Psychical formations such as "stubborn attachments" to objects, tangible or non-corporeal, constitutively create a symbolic substitute for the loss of real inter-personal relationships. Butler's point is that "stubborn attachments" place limitations that inhibit lasting and meaningful relationships with others. Forming "stubborn attachments" to objects, like a clinical diagnosis of "bi-polar" or "schizophrenia" may be therapeutic for some people because it could create a sense of stability. On the other hand, universalizing the formation of "stubborn attachments" toward unhealthy, even destructive ways of living, such as attachments to consumer-driven commodity fetishism, could lead to catastrophic social circumstances on a macro-political level. Such catastrophes could include the depletion of natural resources, global warming, and ecological not to mention economical and socio-political disasters.

In the context of a positive "attachment" a sense could emerge wherein a subject believes, "Yes, now I know how to improve myself." However, in an oppressive situation the symbolic representations designated by the diagnosis may also create a set of circumstances where the subject develops a "stubborn attachment" to the object (the diagnosis) at the expense of living a healthy life. The person may believe - "Oh, I have a diagnosis - I am abnormal," leading to a sense that there is a permanent "brokenness" that forms an allegedly "essential" part of the person's being. My position is that this sense of permanent brokenness as a process is constitutive of a subject becoming accustomed to subjection.

Butler's mode of analysis takes us through a detailed outline of how the latter of the subjects I just described are formed. In turning to Louis Althusser, Butler's point becomes explicitly a Marxist one. When the product of our labor is taken away from us we are supposed to find satisfaction in a maze of money relationships. Unable to literally produce what we want, we are presented with a family, school, and media-instilled social training that leads us to buy products that will give us friendships, sexual satisfaction, and even personal salvation. What has been called consumerism is in fact a manifestation of these alienated relationships to objects, tangible or non-corporeal, that other workers have created and that provide an economic gain for the "Lords" also known as the capitalist owners of the modes of production[3]. However, consumerism is based upon psychic, libidinal investments, made on an unconscious, even instinctual level, that create the ontological basis for seeking out these symbolic substitutes that stand-in for what is lacking in a fully formed subject.

For a moment I want to take this discussion further by saying that the object being sought is fundamentally ethereal; "it" is craved, perhaps even obsessed about, and once "it" is possessed objectively the subject becomes "possessed" ontologically by the desire for more, more, more of "it." The "it" is actually nothing, and constitutes a latent non-corporeal nothingness that is manifested as a tangible something. Obtaining a static sense of pleasure, or the absence of pleasure and pain, and simply being in a state of continuous stable comfort, is virtually impossible in capitalism. Epicurus would not stand a chance in contemporary capitalism. Once a subject finds some sense of stability, unless a certain sense of isolation is cultivated, then there is an eternal recurrence of desire that pokes in and demands something "more." Hence, static pleasure that Epicurus[4] said was the highest form of happiness was in fact the hardest form of happiness to possess.

Most powerful about Butler's turn to Hegel as a pre-requisite to Marx is that she opens a space for a new set of psychic identities/subjectivities to emerge. Therefore, when she discusses the way that some liberationist struggles 
have turned to Hegel she does not mean to define this in terms of reductive Marxist categories of liberationist struggles against capital, but also post-colonial and feminist struggles among others. I am interested in her approach for one particular reason, her book offers a complex analysis of raw power as it works upon any subject be it Mad Pride, or Gay Pride, or any other "We/I" subjectivity that not only seeks representation, but a voice empowered to exist outside of institutional discourses that can inscribe "us" from within. Lordship is inherently dependent upon the Bondsman for recognition.

A Lord only has power insofar as there are subject peoples who recognize that the power is real. However, the way I read The Psychic Life of Power is that the Lordship/Bondsman motif is indicative of a power dynamic that is immanent within the subject. Often the "Master/Slave" dialectic is recognized as somehow detached from the subject, but in actuality the more troubling possibility is that power may saturate the subject from within as an immanent relationship working directly upon the psyche. Master and Slave, Lord and Bondsman, are two sides of the same subject working in dialectical opposition from within.

How does power become in effect pervasive throughout the subject? By creating the illusion of a mind/body dualism that convinced the subject. According to Butler, this process of subjugation occurs when the Bondsman: "Disavows one's body, to render it "Other" and then to establish the "Other" as an effect of autonomy, (and) to produce one's body in such a way that the activity of its production - and its essential relation to the lord - is denied."'[5]

She continues by saying that the Bondsman is essentially required to "be" the Lord's body, but in such a way that the Lord forgets or disavows its activity in producing the Bondsman's. She calls this process of subjection "projection." [6] This process involves a severe sense of denial regarding the nefarious relation between the Self/ Bondsman and the Other/Lord, which acts out within the "site" of the body and the psyche. Butler calls this process "Self-enslavement" as the process is occurring within the domain of a single subject. The Bondsman's labor forms the product yet the product always belongs to the Lord, because the Lord has essentially hired the Bondsman to be its body. The product is marked by the Bondsman's signature, yet the product itself is the property of the Lord.

I interpret this as a process of "repression" that undermines the Bondsman's ability to take ownership of the product that bears the subject's signature. The Bondsman and the Lord are stuck in an economy, perhaps a libidinal economy of desiring-production, that bases the relation on a "position of pure consumption, objects were transitory, and he (the Bondsman and Lord) were defined as a series of transitory desires." [7] For the Lord, nothing seemed to last, perhaps not even the power exerted over the production process. Yet the Bondsman becomes detached from the products him creates, even though the products outlast him. A precarious pseudo-repression occurs which is why she turns to Foucault.

Her reading of Foucault's "Repressive Hypothesis" in juxtaposition to Freud and Hegel is an attempt to show that for every expression of power there are also sights of possible resistance. When power obtains recognition within the body that it seeks to suppress, the proliferation of the power dynamics through body by juridical regimes creates the conditions of a dialectical reversal. Drawing on Foucault, Butler's position is that the "pathos" of a certain condition, assumed to be a bodily or mental dysfunction, inadvertently creates the conditions for a proliferation and mobilization of the cultures it seeks to suppress.

The Icarus Project could be considered one such site of "resistance." An Anarchist Collective, the Icarus Project constitutes a radical approach to mental health and "mad pride" where the alleged pathos associated with mental illness is reinterpreted and re-appropriated into something resembling a "gift." The official Icarus Project website posted its ethos on its homepage stating: "Icarus Project: Navigating the Space Between Brilliance and Madness." I view this as an empowering way of dealing with a mental health diagnosis. However, the Foucaultean/ Butlerian point is that by marginalizing a condition assumed to be a defective "pathos," or emotional state, the juridical regimes, which hinge upon a certain restrictive and contradictory epistemology, ultimately come undone. Once resistance mobilizes it attaches to the terms laid out by the juridical regimes that depict that pathology as "monstrous," or "horrifying." [8] Hence, for Foucault, the marginal body is only constituted after it is repressed. Once repressed the body then can become proliferated throughout a social milieu precisely because it is constituted as an allegedly taboo mode of existence.

The Icarus Project is an online community of mad pride activists that tries to assist people with the experiences of mental health diagnoses by offering coping skills. There is even a radio broadcast network that offers call in talk shows where people can talk to other victims of mental health incarceration to share stories. The goal is empowerment so as to find coping skills that work, even ridding the subjects of their dependency on prescriptions, using meditation, and other alternative therapies not offered by mainstream mental health care. They have chapters in most left leaning 
progressively oriented metropolitan areas such as New York, Philadelphia, Boston, Washington D.C., Chicago, San Francisco, Portland, Seattle, and Austin. There are also smaller chapters such as the one I attended in Binghamton, New York, and the Radical Mental Health Collective in Asheville, North Carolina. It is interesting to note that these are cities often associated with a vibrant arts scene and have numerous vibrant liberal arts colleges in these cities as well. In the Binghamton chapter, I noticed that almost all of the participants were in their early twenties and the meetings entirely consisted of current college students or people who had attended at least some college in the past.

A few years ago I had the privilege of meeting a notable member of the Icarus Project named Ken Rosenthal at a mad pride conference in New York City. Rosenthal's film Crooked Beauty features interview excerpts with notable founders of the Icarus Project including a young artist named Jaks. He was supportive of my paper saying it was inspirational; and he gave me his film for free as a token of friendship. Rosenthal now has many other documentary films on mad studies and they all deal with these ethical issues of madness and alienation. His work shows that there are sensitive artistic people like Jaks who say in his film, "I do not have a spirit that can spend all day in an office cubicle." She also recounts an experience in a college astronomy course where she learned that all life on earth originated from exploding stars, she was disappointed that merely telling people this basic fact did not immediately bring world peace and harmony to everyone on the planet. There is also a very moving anecdote where Jaks tells us she decided to leave home when her mother could not simply say "I love you" without adding the word "but" at the end of the phrase with an addendum of disparaging criticisms added onto the end of the comment.

What is interesting about the Icarus Project as a community of activist oriented "mad" subjects is that we always allowed people the opportunity to vent about these horrible situations and would view these experiences as oppression. Mental health issues were always viewed as symptoms of oppression rather than chemical imbalances in the subject which is why there was such an emphasis on turning away from prescriptions as a cure for these ills. The goal was to address the root causes which were social and political in nature. There is even poetry offered by the Icarus Project because writing and reading is viewed as emotionally therapeutic, to vent, and to know that others experience similar traumas comes as a relief, it alleviates the loneliness. This is the politics of friendship through solidarity and it helps to lighten some of the burden of social alienation associated with having a mental illness, these are safe spaces where one can explore their emotions with other compassionate caring group members who will listen. More importantly, it is free, there is no need for insurance coverage, no drugs to take, this is a much more empowering and cost effective way to treat mental health issues, through the bonds of solidarity offered in lasting friendships. As Jacques Derrida writes; the politics of friendship is about offering community for those who have no community. Icarus is based on that ethical political premise.

What Psychic Life of Power is really about is the status of freedom. Instead of simply stating that freedom is "there" as an intrinsic condition of being, Butler explores a deep concern with subjugated peoples who "stubbornly attach" psychically to the modus operandi of subjection. The promise of the book is to shine light on the inner workings of power and subjection, and to expose the immanence of power ultimately inducing people to liberation. Her point is to be weary of liberation as a "telos" or "end" rather than an open-ended dialectical process. Her book uses Hegel's Master/Slave dialectic to discuss ways in which freedom resolves into unfreedom. In my own words, it is a psychical obsession, much like how conservatives in the media are paranoid about hostile liberals taking over all aspects of American society, and then proceed to only talk about liberals in a paranoid objectification of the object that is allegedly causing their oppression.

Butler argues that this resolution to non-freedom and unhappy consciousness is often overlooked in the Hegelian scholarship that turns to Phenomenology of Spirit specifically to inspire liberation struggles.

A "master/slave" relation implies a mutual dependency. As Butler says, "subjection is literally, the making of the subject, the principle of regulation according to which a subject is formulated or produced." Subjection is not simply about domination from outside the subject, but it designates a restriction in production without which the formation and production of subject would not take place at all. Butler argues that in the work of Foucault it is precisely the formation of a conscience or a "soul" that constitutes the site of this problematic power dynamic. Without a conscience the subject would be unable to form judgments and the whole edifice of the juridical forms of power would cease to exist.

Yet with the formation of the conscience the emotions of guilt, shame, remorse, and unhappiness can work upon the subject to improve the prisoner. The burden of conscience can imprison the prisoner in profound ways other than by simply designating punitive spatial limitations signified by the physical boundaries of the prison itself. If a person can form a conscience, then all sorts of affective measures can be taken to work upon the subject from within by making the prisoner feel guilt, shame, remorse, and other indications that a "soul" has emerged. This 
process is a way of enforcing a sort of "humanizing" effect upon the subject, but as Foucault is quick to point out, "the soul is the prison of the body." [9] However, as I will explore later on in this chapter, the process of cultivating a guilty conscience in a subject can lead to the excessive internalization of negative affects to the point where "selfberatement" occurs and undermines the possibility of experiencing fulfilling happiness.

First I would like to use an illustrative example of this process of producing a "soul" from my time in Icarus Project meetings. In my time involved with the Icarus Project the question of consciousness was always a prevalent issue. In looking at this problem there were several ways in which the sessions often resorted to a projection of selfberatement onto an external Other. Something that bothered me about our particular Icarus meetings was the way the discourse was always enmeshed with "the them." [10] We were preoccupied with power as it related to others 'out there'. For reasons I can only associate with denial we rarely investigated the ways the things we were trying to change influenced our psyches from 'within'.

The Icarus meetings were still encoded with popular discourses based upon the "inner/outer" binary opposition of social relations. To the detriment of radical praxis, we even based our discussions of agency on this shoddily premised binary opposition. In my estimation, the imprint of institutional discourses upon people in the group, including myself was quite profound. Even though intentions existed within the group, and the desire to take radical approaches to the explorations of one's consciousness was always being discussed, there was a pseudo-paranoia underlying the idle talk of the group. "They" were oppressing us.

This leads me to believe that there was still an overwhelming desire to remain attached to the dominant discourse regarding the status of everyone in the group[11] even in the midst of a counter-acting desire to extirpate the self from that very discourse. More often than not our discussions of power were limited by a methodology bound to transcendence, power as something nefarious working upon us from "out there." What we should have done instead was conceptualize power through the lens of immanence, power deriving from within. In this way, power as immanence means power is intimate, encoding us from within. By decoding the "master/slave" dialectic within our own psyches, we could "empower" ourselves to transition the inner-psychical workings of this dialectic.

The master/slave dialectic was clearly being investigated in so many ways, but the realization that "we", the subjects, are in a position that is mutually dependent upon the "others", the masters, was something we never fully realized. After all a King is no longer a King if the subjects refuse to obey. Power needs a subject, but once the subject refuses to be subjected then transformation will occur. By looking back in hindsight, the Icarus Meetings would have benefited from serious reflection on the work of Judith Butler. If we take Judith Butler's analysis seriously, this view of power as "out there" is an unhappy consciousness. It is based on the objectification of the "they" by "us," that creates a splitting off of ideation from affect.

Rather than have a real interaction with the other all of us in the group typically outlined a series of hyperbolic planes that represented the other in hostile terms. Ironically, the urge was always to change the other, to make "them" care about "us" when all the time the power we needed to cope with and improve our conditions was always-already within "us". Often the explicit desire of everyone in the group was to experience some kind of "Unity of Mind" that could not occur in our daily lives because none of us could truly reveal ourselves as 'mad' within the confines of everyday life. The truth is that the master and slave, the lord and bondsman, the self and other are actually constituted from within the mind and body of the thinking subject. Butler's whole point in The Psychic Life of Power is that conscience does not come from outside (God, or society, etc.), albeit the outside is an influence, but the external and internal are interwoven. The object-loss can push the subject to the point where the "self-beratement" or bad conscience is constituted as a relation of immanence within the subject.

The question then becomes, how to avoid resolving subjectivity into some kind of solipsistic or narcissistic reflexivity. If morality is premised upon "self-beratement" and reflexivity, then how does a subject relate to others as a being-in-the-world? This is where a discussion of intentions becomes relevant.

My contention is that intentions are always-already present in any subject. Certainly intentions exist in people who are considered to be outside of political subjectivity such as "the mad." I know this because typical Icarus Project meetings were also about our hoped for intentions, goals, dreams, desires, and ambitions. The constitution of consciousness, and also a therapeutic course of action, is never a matter of abstraction or relations to a transcendental field beyond the self, but daily living as an intimate relation. During any medical decision making process the issue at stake is always a pragmatic consideration of possible outcomes. This entails understanding how an individual experiences a personal sort of consciousness. Lived experience serves the purpose of navigating the immanence of the world. Immanent experience forms the foundation for creating intentionality.

For instance, the ability take corrective action for yourself involves a series of choices and payoffs. Someone 
considering whether to go on medication may weigh these pros and cons; "will this medication stop me from hearing voices? Will my cognitive functioning be reduced to a level where I cannot enjoy life the same way I do without medication?" Most of the time an individual may have no idea how the actions taken within the plane of immanence will actually impact their future way of life. Will going on medication for psychosis benefit or worsen the situation? That is a matter to be understood as a person lives and through the unfolding of time on a very personal, existentialphenomenological level.

In the context of a group in an inter-subjective environment the discussion of what should be done in the aforementioned scenario can become even more complex. A certain segment of the group will agree that the benefits of medicating. These people may argue that the benefits outweigh the negative side effects of hearing voices, however others may disagree and take the opposite position. The group can help with abstractions in the sense that the group itself might be a sort of transcendent field "out there," but in actuality intentionality must be made within the mind of the individual, and within the world as a lived set of experiences that are often times irreversible. I believe, and I may be wrong, that everyone uses reason, intention, and cognitive thinking skills, even people who are considered irrational. Even in the most post-modern attunement to sensuality, surfaces, virtual reality, and desires there is a sentiment of rationality. It is rationality as a perpetual self-overcoming that is implicit within the process of being-in-the-world.

Drawing on Lacan, Butler theorizes that the ideal position of the subject within the symbolic order creates the norm that installs the subject within language and hence as an intelligible being, and she insists that this subject is always produced at a cost. Whatever resists the normative demand by which subjects are instituted remains unconscious.[12]

More often than not how these rational intentions are formed is a result of a thought of immanence not transcendence. What I mean by this is that thinking immanence puts the burden of action squarely upon the subject's shoulders instead of a Transcendent Being that may or may not exist beyond the physical realm. This means that the radical decision making process such as a change of life policy enacted at the level of daily life is within lived ontology. Living lives in the world as something abstracted away like some kind of unattainable Platonic Idea. According to Butler an un-socialized remainder is produced in the psyche that contests the appearances of a lawabiding subject that signifies the limit of normalizing demands.

Forming intentions, meaning the desire and will to act, on this existential-phenomenological level within the world, perhaps in the context of an inter-subjective support group can often times create the necessary conditions for a therapeutic set of circumstances to arise? In later publications I will expound upon these theories to better understand how and why the Subject Group makes inter-subjective intentions on an existential-phenomenological level more probable.

In the formation of intentions, there is an ongoing self-regulating process. Working as little panopticons within all of us, instead of as a regulating eye beyond the self, the internal gaze that folds in upon the subject creates a social environment wherein everyone is policing himself or herself. This could conceivably continue without the intervention of an institutional form of coercion. If everyone decides to ignore those internal panopticons, becoming like lines of flight, then a mobile subject emerges that can escape the grasp of the call of interpellation.

My hypothesis is that within subject groups, subjectivity and intentions could conceivably form out of this selfpolicing environment. A certain panoptic environment produces a non-totalizing totality of many subsequent and differential ontological constructions that could even be therapeutic. A pure group vision has to eject forces that oppose its organic notion of the social Body into a pure externality, for instance in the form of real or perceived paranoia within the subjugated group itself.

Thus re-exerting the will in the context of a radical antagonism between the social body and an Other, for instance the differential social ground to relations inherent within Capitalism, and the external decadent forces serving as the base of Capitalism, creates a nexus playing out upon the consciousness of the subjugated subjects within the activist group. Ultimately the group can decide to remove these paranoid, panoptic discourses when a conscious effort occurs, but this begins only when there is a desire to do so.

Liberation involves the inherent, perhaps immanent, contradictions within the objective laws of capitalist development. The contingency of heterogeneous social forces that work out upon the subject on a micro-political level, perhaps even within the structure of the subject group itself, can create a series of negative utopias where discursive spaces are opened up and unsavory desires safely emerge. Radical critiques, Thanotopic-drives, and otherwise repressed desires could conceivably be expressed in this environment. Any project where agency is asserted involves the autonomous intervention of will within the context of history. My position is that agency also 
involves the transformation of habitual psychical refrains. Literally expressing desires in a different way by creating new subjectivities, new thoughts, new modes of expression, can be an inherently revolutionary form of praxis on a micro-political level and this may or may not lead to a ripple effect upon the mezzo and macro-political schema and strata within the rest of capitalism. In fact, the obscure aspects of my own writing have been an attempt to obfuscate the obvious in the hopes of playing with the discursive possibility of creating new thoughts.

The presage to active living is the thought of immanence in the sense that collective will is necessitated by my active involvement in the world that envelops me, or us. I agree with Felix Guattari who argued that a group devoted to collective action should be pre-eminently interested and aware of its own "death." The allusion to death carries a double meaning. First, death means literal material death in the sense of the end of the physical body itself and the end to suffering, then there are Thanotopic-drives. A death-drive expressed in a subject group involves the formation of self-beratement or self-destructive intentions. The expression of death-drives should be born out of an open articulation of seemingly undesirable paroxysms; "I hate my life. Here is why!" or worse, "I have had suicidal thoughts because..."

This sort of statement occurred at nearly every Icarus Project meeting. The group would then begin an honest interrogation into the reasons why the person would make such a statement. At times these confessions spiraled into a collective feeding frenzy where others in the group would open up to share their Thanotopic-thoughts. We would never blame the person who was confiding because there was an almost unspoken pact in the group that meant nobody within the group was ever to blame for their situation. Some folks were looking for pity, but for the most part it was accepted that blame was something that family members would dish out and Icarus was supposed to be a safe place to vent. So the airing of undesirable paroxysms was very common and it often initiated the discussions on an extremely personal level. Yet, this was something that made Icarus different from most other support groups I have been involved with. In an Icarus meeting the stated purpose was to offer a safe place to openly express madness. Other support groups were immersed in the subjection perpetuated by medical discourses, namely because a typical Bi-Polar support group often starts from the premise that the members of the group are suffering from a "disease." On the other hand, Icarus began from the premise that madness was a gift to be cultivated and safely explored. I found the Icarus Project's ideology to be much more open to the free expression of madness - where it was completely acceptable to "be crazy together" as one member put it.

The open expression of gifts deemed to be socially deviant or abnormal that created a wonderfully selfempowering environment to talk in ways that allegedly "sane" people would most likely consider strange. At the end of most meetings I often left with a feeling that a symbolic veil had been lifted and my pure essence had been revealed.

Even in an Icarus Project meeting there was still plenty of 'self-beratement' that went into discussions of past traumas. Sometimes a sadistic revelation about a childhood setback would snowball into full-blown conversations about a person's previous suicide attempts. Other times it would turn into long-winded rants about the perception that other society was full of people who "don't care about anything." My point is that all of these conversations involve being-towards-death and on some level. Specifically, a death within the subject emerges in the sense that there is an attempt to kill off the negative feelings by pouring on more guilt, shame and anger. This often compounds negative emotions and spirals a person further into a subjugated position towards them and others. In some instances, an emotional release may occur where the person would feel better by sharing something traumatic, and other times a confession would build into a full blown anxiety attack.

The premise is that when a group fails to remain useful a person should leave the group and re-evaluate whether it is serving that person's needs. When a subject group no longer serves a purpose it should be disassembled. I remember talking to someone on the Icarus discussion boards about the way the Binghamton chapter broke down and ended. His response was all about this sort of confrontation with death. A paraphrasing of his response was something like, "Icarus is a collectively run group. If it serves no purpose for you then take a step back. There should be no pressure to force you to engage with Icarus project. If you are helped by it that's great, but if not, then you should try something else." The death of the group was viewed as quite possibly the most therapeutic event in the life of the group.

Another meaning of Death is far more figurative and it involves a death or finitude of the group itself. This second meaning involves thinking about how to pragmatically deconstruct the group itself once the stated political goals have been accomplished. A thought of finitude does not involve a thought of failure, but of achievement. Living constitutes a dialectical process of self-overcoming that only ceases in death. Once a goal has been accomplished are there mechanisms involved in the structure of the group itself that would allow for a non-hierarchical power 
dynamic within the end product. Will the end product be stripped away by the precarious social milieu predominated by a Master/Slave dialectic ala capitalist production? When the subject group accomplishes its purposes how will it produce its own death? More than likely because its members have accomplished what they have set out to do the death of the group will be accepted happily. Nobody needs a lumbering bureaucratic institution outlasting its purpose.

Oftentimes at a typical Icarus Project meeting the connections could be made between individually lived alienations, and life within a broader social field like capitalism in general. One could get the feeling that, as Bernard Stiegler points out, "Capitalism has lost its mind." [13] We would constantly theorize about problems related in part to what Deleuze called, "a society of control," and it was typically assumed that this sort of society of control was creating mass apathy.

While I disagree with the theory that there is some kind of mass apathy inhibiting political will, my view is that there are many countervailing discourses that create a situation resembling what Deleuze and Guattari called "antiproduction," wherein people are convinced that what they are doing is in their own self-interest when in fact it is not. The famous question from Anti-Oedipus is one that Judith Butler deals with in Psychic Life of Power, "Why do people fight for their servitude as if it were their salvation?" This question is still relevant when discussing the Icarus Project.

My conclusion from observing the Icarus Project is that anti-production, or desiring counter-productive ideologies, always serves the purpose of creating political enemies. When discussing "anti-production" it is always a matter of "them, over there," who do not know what they are doing is against their self-interest, yet "we, us over here," know better.

Another conclusion that can be drawn is that the problem of political agency is much more complex than simply projecting the appearance of a ruse upon someone whose political positions disagree with "mine." In most cases during the Icarus Project meetings doing this abstracts the "their" position, perhaps changing it into some kind of transcendental force beyond the world. I prefer Foucauldean analysis over Sartrean in the sense that Foucault conceptualized all types of political will as a result of desiring production within a social milieu that has many countervailing discourses; a point he appropriated from Friedrich Nietzsche's Genealogy of Morality. In addition, Foucault's research showed counter-productive hegemonies that may create conflicting positions, interests, and ultimately conflicting forces often pull political will in a multitude of contradicting directions. In many ways Michel Foucault is the most interesting interpreter of Nietzschean Genealogy; a point that Sartre elided; overlooked; perhaps even misread. This is precisely Judith Butler's point in Psychic Life of Power when she appropriates a Foucauldean / Nietzschean / Althusserian methodology to unravel the "unconscious attachments to subjection.”[14]

This is also a major point in the work of the Marxist Theorists; Michael Hardt and Antonio Negri. Unlike the early work of Antonio Negri; such as Marx Beyond Marx; and the Savage Anomoly; in his collaborative with Michael Hardt; and after the mid-1980's collaborations with Felix Guattari entitled “Communists like Us, ”Negri's work begins to engage much more with Deleuze and Guattari to theorize that capital functions on a plane of immanence. The following quotation seems to be a new theorization that offers a synthesis of the Foucaultean / Nietzschean / Althusserian genealogical analysis of the capitalist mode of production and the methodologies offered by Deleuze and Guattari that show an intensification of exploitation leading to the suffering that explodes into antagonistic lines of flight:

“Through relays and networks of relationships of domination, without reliance on a transcendent center of power. It tends historically to destroy traditional social boundaries, expanding across territories and enveloping always new populations within its processes."[15]

The plane of immanence forms the base, or the horizon of the event.[16] While they are undoubtedly echoing the Communist Manifesto; "in capitalism all that is solid melts into air," The way to situate Hardt and Negri; is through the lens of his early solo projects written on Spinoza and the Grundrisse; which centered on "conatus" and antagonisms over the wage. These are the major movements labor makes striving towards its own liberation. In engaging with Deleuze and Guattari; rather than Althusser (whose invitation inspired the work Marx Beyond Marx); there is a way that these intensifications of suffering and exploitation become the sites of antagonistic-conatus; that explode into lines of flight.

Hardt and Negri's argument is powerful in that there is not a transcendent center to capitalist subjectivity. As the intensification of exploitation reveals this is move from contradicting discourses (as many often misunderstand Foucault as a discourse theorist; or a philosopher of language via a misappropriation through the worst kinds of 
Heideggerian-Derridean a-rationalist deconstructionists of the "linguistic turn"); many countervailing discourses, interests, and even desires that intersect in competition along many points where hegemony is contested. This means that there is no single location where resistance can attack, but power may be aligned in a continuum of nodes or loci where resistances can emerge along this plane of immanence.

Even a seemingly innocuous Icarus Project meeting, or a thread of posts on the website, can have a viral impact on a segment of the plane of immanence if the consciousness and subjectivity produced somehow finds other networks where unrepresented voices can be articulated openly. The exact effects are perhaps unknown, much like deciphering the correct course of therapeutic action with the aforementioned patient deciding whether or not to take medication. The fact that an antagonism is formed at some point along the plane of immanence may have an impact upon other seemingly unrelated areas of the social field. My argument is not meant as an abstraction along the lines of the bad infinity of some types of Chaos Theory where a butterfly flaps their wings in Jakarta and suddenly world history is radically altered. My point is that actions in one area may in fact have an impact upon the rest of society in very concrete ways, but we do not always know the outcome or what the impact "out there" will be. I also want to stress that actions might have unintended consequences, or perhaps undesirable consequences, and almost all actions are in fact consequential in nature. Even inaction has consequences. However, the nature of these consequences is typically unknowable until they actually happen.

For instance, there is a common assertion among members of the Icarus Project, and it is common on the discussion boards which to paraphrase goes something like this: "The diagnostic categories that my psychiatrist uses to diagnose me are insufficient and I do not identify with them because I am a unique and special individual that cannot be subjected to classification or diagnosis. Therefore I am not ill, or at the very least my diagnosis is an insufficient, my identity is far more complex than that, etc."

This discourse falls squarely within the domain of a humanist brand of immanence because it implies that we are all unique individuals. My point is that we are all allowed to appropriate a space for ourselves within the social order, but we are never allowed to actually deconstruct the very base of the social order or undermine the very premise of the symbolic order.

I believe that everyone seeks pleasure. Happiness is the obtainment of pleasure, and although some psychoanalysts like Jacques Lacan have argued that "happiness is not necessarily about getting what you want," I disagree. Sought after pleasure forms the basis of what constitutes happiness. Michel Foucault in History of Sexuality Volumes $2 \& 3$ is masterful in his understanding of how pleasure is used. He describes the Greek way of life in thorough detail that involved equilibrium of pleasure, or what he referred to as the use of pleasure. For the Greeks, seeking beauty involved its usefulness, not its excess. Enjoying fine food, or sex, in balance and not for the sake of seeking an excess of pleasure creates a greater sense of joy because it brings balance to life.

Often in Foucault this type of care of the self occurs when a balance is struck between the self and the other and it can only come about through an authentic being-towards-death. Why? Understanding the finitude of life creates a desire to maximize life and to maximize the pleasure of living. Altruism is balance, which Foucault argued was the highest form of pleasure. So, I'm not just studying philosophy to gain wisdom for myself but to someday give back some of my wisdom to others through teaching, or to facilitate an education process that leads students to understand that they in fact have wisdom in themselves. Usually this sort of role-playing was always prevalent in a typical Icarus project meeting. Each of us played the role of group facilitator and it was always a matter of striking a balance between taking wisdom for myself, and providing wisdom or advice for others. There was always a give and take process inherent in every Icarus group meeting.

It is also important to note when studying Deleuze, Negri, or even Foucault for that matter, that they are deeply troubled by the way so-called modern society, with its excesses of disciplinary power and pseudo-rationalism, tended to manufacture mass subjectivities. Foucault, and this can also be said of Deleuze, Negri, and even their notable predecessors in Marx and Nietzsche, was deeply troubled by what it means for certain notions, such as "sanity", to become normalized, and to ultimately enter the world of human knowledge (or epistemes) and practice not merely as operational constructs, but as universal "truths of being." Along with Foucault one might argue here that to downplay concerns of normalization is to underestimate the power of discourse to literally shape and mold human behavior through the mass production of ideologies, and beliefs, which create the horizon-line of what constitutes the realm of the thinkable.

In contemporary society certain "facts" of human life are presumed to be universal, eternal, everlasting, and transcendent, when in fact what happens is that the deviation from particular social norms, perhaps thinking the unthinkable, or even stretching the realm of subjectivity to include ideas and emotions that are irreducible to the 
linguistic-form (or finding expression of thoughts that do not easily reduce down to words, but are better expressed in a flurry of seemingly disconnected allusions, images, or emotive motifs) can create the presumption of being "mad." In fact, one of the presuppositions that Deleuze only hints at in his book on Bergson where he discusses temporality as duration, is that someone who is thought to be a "schizo-subject," may in fact be experiencing a non-linear conception of time, and may be expressing thoughts in a circular, or even less organized flow, that makes sense inside that subjects head, but may be impossible to communicate with another human being. Often times this sort of expression appears as the breakdown of "Rational thinking," but in fact, what is happening, and R.D. Laing points this out many times, is that the "psychotic" can make sense, it just takes an incredible amount of time and effort on behalf of a trained therapist to decipher the code, because the "psychotic" subjects thoughts are for him or herself. A meaning is being communicated, but it is a deviation from the normal forms that so-called "sane" discursive practices take.

In essence, what the work of Deleuze, Foucault, and Negri, have in common with the "psychotic" is that they are breaking with the lazy, habitual, perhaps even genealogical presuppositions of modernist discourse that has turned the joy of thinking into some technical professionalized institutionally austere form of pseudo-rationalist philosophical carcass. Why has this happened? And why is Western philosophy haunted by madness, the allegedly irrational subject that has no subjectivity? It is because there is a long Western philosophical tradition leading back to the Greeks that says Ethos and Logos should predominate over Pathos.

In the Western philosophical tradition, it is commonly accepted that Ethos, or ethics, the ability to make reasonable judgments about right and wrong, along with Logos, or logical thinking, giving a coherent "argument," should supersede Pathos, emotional or affective argumentation based on feelings. To make a statement based on Pathos is typically viewed as being less than credible. Yet, I would say that judging by the track record of Western philosophy, specifically the monstrosity that is contemporary analytical thought, one could argue that the privileging of Ethos and Logos has yet to produce desirable effects.

The reason for turning to the Icarus Project as a site of "antagonistic-conatus" is this diminution of the Pathos in the Western philosophical tradition has had a direct impact upon the treatment of the "Mad" for the simple reason that to have uncontrollable affects and emotions has been viewed as being "Pathological." In medical discourse, having uncontrollable emotions or being swept away by strong emotions is viewed as a mental illness. To put my conclusions in the terms passed on by Karl Marx, the "grund-werke" of capitalism must change.

\section{Endnotes}

1. Leary, Warren E. "Genetic Engineering of Crops Can Spread Allergies Study Says," New York Times, 14 March, 1996.

2. Judith Butler. Bodies That Matter. Routledge Press. New York. P.67.

3. Phil Brown. (1974). Toward a Marxist Psychology. Harper and Row Publishers. P. 25

4. Epicurus. (2006). Principle Doctrines. The Longman Standard History of Philosophy. Edited by Daniel Kolak and Garrett Thompson.

5. Judith Butler. (1997). Psychic Life of Power. "Hegel's Unhappy Consciousness." P. 35.

6. Judith Butler. (1997). The Psychic Life of Power. Ibid.

7. ----.(1997). The Psychic Life of Power. P.39.
8. Arnold Davidson. (2004). The Emergence of Sexuality. Harvard University Press.

9. Judith Butler. The Psychic Life of Power. P.85.

10. Heidegger, M. (1962) Being and Time. HarperCollins.

11. What I mean is that even though some people vocalized their discontent with diagnostic labels there was still an overwhelming sentiment among these people resembling what some other activists have labeled, "Mad Pride." I have problems with this label because it still resorts to the term "Mad" to identify the members of the group. By saying "I'm mad" or as some people in Icarus Project said from time to time, "I come to this group to feel comfortable expressing my madness among people like me," I always felt as though this sort of idle talk led to a complacency in the understanding that the people in the people in the group were abnormal. I have problems with this for 
the reasons outlined in my discussion of being-in-theworld; I feel as though mood disorders are not always "disorders" or deviances from the norm, but excesses of emotion and desire. It's not that we, "the mad" are outside the limits of normalcy, but that we have an excess of completely normal emotions, we feel in excess to the point where it encompasses our entire being. Since other folks are fail to feel on a deep profound level, they are most likely walking around like living dead people or "zombies," and that is more akin to being insane than being deeply affected by, for instance, the thought of the finitude of life and the facticity of impending death. Basically "the mad" are people who feel things, or think things, or act out in a way that other people have killed in themselves. There is a being-towards-death implicit in being "Mad," because often times mad person has yet to actually kill their ability to feel, what people call madness is an intensity of the ability to intensely feel the ups and downs of life. An appropriation of the word "Mad" was happening that felt a bit odd to me.
12. Judith Butler. The Psychic Life of Power. P. 87

13. Stiegler, B. Spirit, Capitalism and Superego. Conference at Northwestern University, May 2006.

14. Judith Butler. Psychic Life of Power. P.88.

15. Hardt, M. and Negri, A. Empire. Harvard University Press. "Passages of Production," p.326-329.

16. Deleuze, G. and Guattari, F. (1996). What is Philosophy? "Plane of Immanence". Columbia University Press. P.36. 